\section{BRAZIULIAN JOURNAL \\ OF MEDICAL AND BIOLOGICAL RLSF.ARCH}

www.bjournal.com.br
ISSN 0100-879X

Volume 42 (11) 993-1118 November 2009

BIOMEDICAL SCIENCES

AND

CLINICAL INVESTIGATION

Braz J Med Biol Res, November 2009, Volume 42(11) 1015-1019

Hydrogen peroxide induces a specific DNA base change profile in the presence of the iron chelator 2,2' dipyridyl in Escherichia coli

D.L. Felício, C.E.B. Almeida, A.B. Silva and A.C. Leitão

The Brazilian Journal of Medical and Biological Research is partially financed by
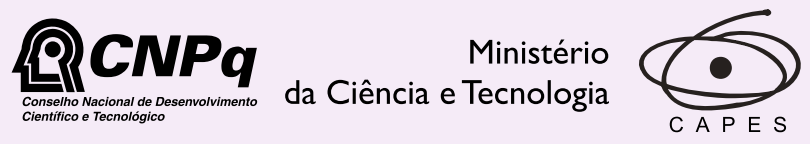

Ministério da Educação

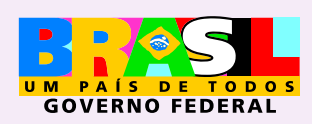

Institutional Sponsors 


\title{
Hydrogen peroxide induces a specific DNA base change profile in the presence of the iron chelator 2,2' dipyridyl in Escherichia coli
}

\author{
D.L. Felício ${ }^{1}$, C.E.B. Almeida ${ }^{2}$, A.B. Silva ${ }^{1}$ and A.C. Leitão ${ }^{1}$ \\ ${ }^{1}$ Laboratório de Radiobiologia Molecular, Instituto de Biofísica Carlos Chagas Filho, \\ Universidade Federal do Rio de Janeiro, Rio de Janeiro, RJ, Brasil \\ ${ }^{2}$ Laboratório de Radiobiologia, Instituto de Radioproteção e Dosimetria, \\ Comissão Nacional de Energia Nuclear, Rio de Janeiro, RJ, Brasil
}

\begin{abstract}
Pretreatment of Escherichia coli cultures with the iron chelator 2,2'-dipyridyl (1 mM) protects against the lethal effects of low concentrations of hydrogen peroxide $(<15 \mathrm{mM})$. However, at $\mathrm{H}_{2} \mathrm{O}_{2}$ concentrations equal to or greater than $15 \mathrm{mM}$, dipyridyl pretreatment increases lethality and mutagenesis, which is attributed to the formation of different types of DNA lesions. We show here that pretreatment with dipyridyl $(1 \mathrm{mM})$ prior to challenge with high $\mathrm{H}_{2} \mathrm{O}_{2}$ concentrations $(\geq 15$ mM) induced mainly $\mathrm{G}: \mathrm{C} \rightarrow \mathrm{A}: \mathrm{T}$ transitions (more than $100 \mathrm{X}$ with $15 \mathrm{mM}$ and more than $250 \mathrm{X}$ with $20 \mathrm{mM}$ over the spontaneous mutagenesis rate) in E. coli. In contrast, high $\mathrm{H}_{2} \mathrm{O}_{2}$ concentrations in the absence of dipyridyl preferentially induced $A: T \rightarrow T: A$ transversions (more than 1800X and more than 300X over spontaneous mutagenesis for 15 and $20 \mathrm{mM}$, respectively). We also show that in the fpg nth double mutant, the $r p o B$ gene mutation (Rifs-RifR) induced by $20 \mathrm{mM} \mathrm{H}_{2} \mathrm{O}_{2}$ alone (20X higher) was increased in 20 $\mathrm{mM} \mathrm{H}_{2} \mathrm{O}_{2}$ and dipyridyl-treated cultures (110X higher), suggesting additional and/or different lesions in cells treated with $\mathrm{H}_{2} \mathrm{O}_{2}$ under iron deprivation. It is suggested that, upon iron deprivation, cytosine may be the main damaged base and the origin of the pre-mutagenic lesions induced by $\mathrm{H}_{2} \mathrm{O}_{2}$.
\end{abstract}

Key words: Hydrogen peroxide; Dipyridyl; Mutagenesis; Iron; Fenton reaction

\section{Introduction}

In Escherichia coli, it has been demonstrated that $\mathrm{H}_{2} \mathrm{O}_{2}$ induces cell death by two different modes of action as a function of $\mathrm{H}_{2} \mathrm{O}_{2}$ concentration, both of which are accompanied by enhanced mutagenesis $(1,2)$. Oxidative DNA damage induced by hydrogen peroxide is thought to occur through the Fenton reaction in the Haber-Weiss cycle. Our group and others have demonstrated (2-4) that pretreatment with the iron chelators 2-2'dipyridyl, 1-10 phenanthrolene or deferoxamine protects $E$. coli cells against the lethal effect of $\mathrm{H}_{2} \mathrm{O}_{2}$, suggesting that ionic iron is the main transition metal that mediates its genotoxicity (5). Dipyridyl also protects the cells against the oxidative lesions produced by UV-B radiation (6). Asad and Leitão (3) have proposed a different pathway for DNA damage induced by $\mathrm{H}_{2} \mathrm{O}_{2}$ when cells are depleted of iron because DNA lesions produced under these conditions were repaired even in an exonuclease III
(xthA)-deficient mutant (3). It was thought that this pathway would occur through the Fenton reaction mediated by transition metals other than iron. Indeed, copper ions have been implicated as candidates to mediate this pathway. It was suggested that copper plus $\mathrm{H}_{2} \mathrm{O}_{2}$ would generate different types of DNA lesions or a higher number of the same lesions that are generated through the iron-mediated Fenton reaction (7). Following this characterization, Asad et al. (8) detected the increased sensitivity of fpg and uvrA mutants to $\mathrm{H}_{2} \mathrm{O}_{2}$ challenge when iron deprived. Based on the fact that oxidation involving copper generates a significant amount of 8oxo-G and that Fpg and UvrA play an important role in repairing this lesion, Almeida et al. (7) have suggested that 80xo-G should be the most important DNA lesion produced by $\mathrm{H}_{2} \mathrm{O}_{2}$ challenge in iron-depleted cultures $(9,10)$. The SOS response is also believed to play an important role in cell

Correspondence: A.C. Leitão, Laboratório de Radiobiologia Molecular, Instituto de Biofísica Carlos Chagas Filho, UFRJ, CCS Bloco G, 21941-902 Rio de Janeiro, RJ, Brasil. E-mail: acleitao@biof.ufrj.br

Research supported by CNPq, FAPERJ and CAPES.

Received May 13, 2009. Accepted August 21, 2009. Available online October 26, 2009. 
survival after treatment with $\mathrm{H}_{2} \mathrm{O}_{2}$ in the presence of iron chelators (9).

In the present study, we investigated $\mathrm{H}_{2} \mathrm{O}_{2}$-induced mutagenesis under iron deprivation using a reversion test with a series of $E$. coli mutant strains (11) as well as a forward mutation test (12) using base excision repair mutant strains.

\section{Material and Methods}

\section{Bacterial strains}

The bacterial strains used are derived from $E$. coli $\mathrm{K}-12$ and are listed in Table 1.

\section{Growth conditions}

Bacterial cultures were grown overnight in M9 minimal medium (13) containing glucose $(4 \mathrm{~g} / \mathrm{L})$ supplemented with $2.5 \mathrm{mg} / \mathrm{mL}$ casamino acids and $1 \mu \mathrm{g} /$ $\mathrm{mL}$ thiamine at $37^{\circ} \mathrm{C}$ under shaking. The supplemented medium was designated M9S. A starting inoculum $\left(0.25 \mathrm{~mL}, \approx 10^{8}\right.$ cells) was taken from these cultures and the cells were grown in $10 \mathrm{~mL}$ fresh M9S medium until the mid-exponential phase $\left(2 \times 10^{8}\right.$ cells $\left./ \mathrm{mL}\right)$.

\section{Survival experiments}

Cultures in the mid-exponential phase of growth (pretreated or not with $1 \mathrm{mM}$ dipyridyl) were challenged with $20 \mathrm{mM} \mathrm{H} \mathrm{O}_{2}$ (30\% perhydrol; Merck, 7722-84-1, Brazil) for $20 \mathrm{~min}$ (CC strains) or $5 \mathrm{~min}$ (AB1157 and base excision repair mutant strains) in M9S medium at $37^{\circ} \mathrm{C}$ under shaking. Residual $\mathrm{H}_{2} \mathrm{O}_{2}$ was inactivated by the addition of excess catalase (5 $\mathrm{\mu g} / \mathrm{mL}$; EC 1.11.1.6 Sigma 9001-05-2, USA). Samples were collected at the end of the incubation time, diluted in M9 salt solution, and spread on lysogeny broth (LB) medium (13) solidified with 1.5\% agar (Difco). The colony forming units (CFU) were scored after overnight incubation at $37^{\circ} \mathrm{C}$.

\section{Pretreatment with dipyridyl}

Cultures in the mid-exponential growth phase were incubated with the iron chelator dipyridyl (1 mM; 2,2'- bipyridine, Sigma, 366-18-7) for $20 \mathrm{~min}$ in M9S medium at $37^{\circ} \mathrm{C}$, with shaking. Treatment with the metal ion chelator alone did not affect cell viability (data not shown). Cultures treated with 1 $\mathrm{mM}$ dipyridyl are referred to as iron-depleted culture.

\footnotetext{
Analysis of the Lac $\longrightarrow$ Lac $^{+}$mutagenesis induced by $\mathrm{H}_{2} \mathrm{O}_{2}$

Mutagenesis assays for transitions and transversions are based upon the $\mathrm{Lac}^{-} \rightarrow \mathrm{Lac}^{+}$reversion of specific mutations in the lacZ gene located on an F'-plasmid described by Coulondre and Miller (14) and Cupples and Miller (11).
}

Escherichia coli strains

Relevant genotype

Reversion event

$A: T \rightarrow C: G$

$\mathrm{G}: \mathrm{C} \rightarrow \mathrm{A}: \mathrm{T}$

$\mathrm{G}: \mathrm{C} \rightarrow \mathrm{C}: \mathrm{G}$

$\mathrm{G}: \mathrm{C} \rightarrow \mathrm{T}: \mathrm{A}$

$A: T \rightarrow T: A$

$A: T \rightarrow G: C$

ara $^{-} . \Delta(\text { lac }- \text { proB })_{\mathrm{XIII}}\left[\mathrm{F}^{\prime}\right.$ lacl' $\mathrm{Z}^{-}$. pro $\left.^{+}\right]$

$F^{-}$thr-1, leuB6, thi-1, argE3, his-4, proA2, lacY1, galK2, xyl-5, ara-14, rspL13, tsx-33, supE44

As AB 1157, but $n$th

As $A B$ 1157, but fpg

As AB 1157, but $n$th fpg

${ }^{*}$ The CC strains were a gift from Prof. J.H. Miller (University of California, Los Angeles, CA, USA). The BW strain was a gift from Dr. Bernard Weiss (University of Boiteux (DRR, CEA Fontenay aux Roses, France). The AB strain was from our

Reversion is examined in a set of strains (CC101 to 106) in which the $\mathrm{Lac}^{+}$phenotype is recovered after specific base substitution restores codon 461 of the lacZ gene to GIn. We have screened base changes using the $\mathrm{CC}$ strains after treatment with 15 and $20 \mathrm{mM} \mathrm{H}_{2} \mathrm{O}_{2}$ for 20 min with or without dipyridyl (1 $\mathrm{mM})$ pretreatment. Cultures in the mid-exponential growth phase were challenged as indicated in the section Survival experiments. Aliquots $(0.8 \mathrm{~mL})$ were taken for survival and mutagenesis experiments, centrifuged for $4 \mathrm{~min}$ at $9500 \mathrm{~g}$ and resuspended in $0.4 \mathrm{~mL}$. An aliquot of $0.2 \mathrm{~mL}$ was added to $2 \mathrm{~mL}$ LB and incubated for $20 \mathrm{~h}$ at $37^{\circ} \mathrm{C}$ with shaking ( $150 \mathrm{rpm}$ ). Next, a $0.1-\mathrm{mL}$ portion was spread on minimal medium containing $0.4 \%$ lactose as a carbon source (11) and incubated for $72 \mathrm{~h}$ at $37^{\circ} \mathrm{C}$ to allow growth of $\mathrm{Lac}^{+}$revertants. Viable cell numbers in the 20 -h culture were counted on LB plates after $24 \mathrm{~h}$ at $37^{\circ} \mathrm{C}$. The mutation frequency is reported as number of mutant cells per $10^{8}$ viable cells. Data are reported as means \pm SEM of three experiments, as indicated in the tables. Fold increase in mutation frequency (base substitution) was compared between strains by ANOVA and the Tukey-Kramer multiple comparison test (GraphPad InsTat, GraphPad Software Inc., USA). The level of significance was set at $P<0.01$ in all analyses.

As a control we measured the sensitivity of $\mathrm{CC}$ strains to challenge with $20 \mathrm{mM} \mathrm{H}_{2} \mathrm{O}_{2}$ and observed that the survival was about $10 \%$ and for dipyridyl-pretreated cells the survival was 2 to $5 \%$ (data not shown).

\section{Analysis of the Rifs $\longrightarrow$ Rif $^{R}$ mutagenesis induced by $\mathrm{H}_{2} \mathrm{O}_{2}$}

Mutagenesis experiments were performed as described by Sedgwick and Goodwin (12). Cells in the mid-exponential 
phase of growth, pretreated with $1 \mathrm{mM}$ dipyridyl or not (20 min), were treated with $20 \mathrm{mM} \mathrm{H}_{2} \mathrm{O}_{2}$ for $5 \mathrm{~min}$. All strains showed at least $60 \%$ survival after the $\mathrm{H}_{2} \mathrm{O}_{2}$ challenge. Aliquots were taken for survival experiments, and $0.1-\mathrm{mL}$ samples were added to $3 \mathrm{~mL}$ of melted LB containing $0.75 \%$ agar, which was then layered on 15-mL LB plates. An additional 3-mL layer was added to the plates, which were then incubated at $37^{\circ} \mathrm{C}$ for $5 \mathrm{~h}$ to allow cell division and mutation fixation. After this period, a final 3-mL layer of melted LB containing $800 \mu \mathrm{g} / \mathrm{mL}$ rifampicin (Sigma 13292-46-1) was added and plates were then incubated for $16 \mathrm{~h}$. Diffusion of the antibiotic through the medium led to a final concentration of $100 \mu \mathrm{g} / \mathrm{mL}$ rifampicin. Rifampicin-resistant CFU represented cells with a mutated $r p o B$ gene and mutation frequency was expressed as the ratio between the number of rifampicin-resistant CFU and the number of viable cells after treatment detected in the corresponding survival experiment.

\section{Results and Discussion}

To analyze the nature of the lesions produced when bacterial cultures are pretreated with 2-2'dipyridyl and challenged with $\mathrm{H}_{2} \mathrm{O}_{2}$ at high concentrations, we conducted mutagenesis assays for transitions and transversions based upon the Lac ${ }^{-}$ $\rightarrow \mathrm{Lac}^{+}$reversion of specific mutations in the lacZ gene located on an F'-plasmid described by Coulondre and Miller (14) and Cupples and Miller (11).

A clearly predominant $\mathrm{A}: \mathrm{T} \rightarrow \mathrm{T}: \mathrm{A}(\mathrm{CC} 105)$ transversion was seen when strains were treated with $\mathrm{H}_{2} \mathrm{O}_{2}$ concentrations $\geq 15 \mathrm{mM}$ (Table 2). On the other hand, these concentrations induced a completely different pattern of base changes in cultures pretreated with 2-2'dipyridyl. In this case there was a clear preference for $\mathrm{G}: \mathrm{C} \rightarrow \mathrm{A}: \mathrm{T}$ (CC102) transition instead of the massive $A: T \rightarrow T: A$ (CC105) transversion induced by $\mathrm{H}_{2} \mathrm{O}_{2}$ alone (Tables 2 and 3 ). It should be noted that $A: T \rightarrow T: A$ (CC105) base substitution appears as the second highest mutation frequency of base substitution when $\mathrm{H}_{2} \mathrm{O}_{2}$ treatment is performed under iron deprivation (Table 3 ).

By our characterization of DNA base substitution induced by treatment with high concentrations of $\mathrm{H}_{2} \mathrm{O}_{2}$ upon iron deprivation, we obtained a clear difference in the profile of DNA lesions induced in the two situations. $A: T \rightarrow T: A$ transversion induced by $\mathrm{H}_{2} \mathrm{O}_{2}$ can be related to translesion synthesis at AP sites that is strongly dependent on SOS

Table 2. Mutagenesis of CC culture strains exposed to $\mathrm{H}_{2} \mathrm{O}_{2}$.

\begin{tabular}{|c|c|c|c|c|c|c|}
\hline \multirow[t]{2}{*}{ Strain } & \multirow[t]{2}{*}{ Substitution } & \multirow{2}{*}{$\frac{0 \mathrm{mM} \mathrm{H}_{2} \mathrm{O}_{2}}{\text { Mut } / 10^{8} \text { cell }}$} & \multicolumn{2}{|c|}{$15 \mathrm{mM} \mathrm{H}_{2} \mathrm{O}_{2}$} & \multicolumn{2}{|c|}{$20 \mathrm{mM} \mathrm{H}_{2} \mathrm{O}_{2}$} \\
\hline & & & Mut $/ 10^{8}$ cell & Fold increase & Mut $/ 10^{8}$ cell & Fold increase \\
\hline CC101 & $A: T \rightarrow C: G$ & $1.7 \pm 0.3$ & $12.5 \pm 1.5$ & 7.4 & $55.3 \pm 30.9$ & 32.5 \\
\hline CC102 & $\mathrm{G}: \mathrm{C} \rightarrow \mathrm{A}: \mathrm{T}$ & $0.5 \pm 0.3$ & 0.0 & 0.0 & 0.0 & 0.0 \\
\hline CC103 & $\mathrm{G}: \mathrm{C} \rightarrow \mathrm{C}: \mathrm{G}$ & $0.6 \pm 0.2$ & $6.0 \pm 4.2$ & 9.8 & $18.4 \pm 10.8$ & 30.2 \\
\hline CC104 & $\mathrm{G}: \mathrm{C} \rightarrow \mathrm{T}: \mathrm{A}$ & $3.3 \pm 1.4$ & $33.7 \pm 5.7$ & 10.2 & $50.0 \pm 11.5$ & 15.2 \\
\hline CC105 & $\mathrm{A}: \mathrm{T} \rightarrow \mathrm{T}: \mathrm{A}$ & $0.5 \pm 0.2$ & $978.8 \pm 242.0^{*}$ & 1856.9 & $162.9 \pm 6.9^{*}$ & 309.0 \\
\hline CC106 & $A: T \rightarrow G: C$ & $0.3 \pm 0.1$ & $0.5 \pm 0.1$ & 1.7 & $0.1 \pm 0.0$ & 0.2 \\
\hline
\end{tabular}

Cultures in the mid-exponential phase of growth in M9S medium at $37^{\circ} \mathrm{C}$ under shaking were exposed to $\mathrm{H}_{2} \mathrm{O}_{2}$ treatment for $20 \mathrm{~min}$. The data represent the mean of at least 3 experiments and are used in Table 3 and Figure 1. ${ }^{*} \mathrm{P}<0.01$ compared to all other strains (Tukey-Kramer test).

Table 3. Mutagenesis of $\mathrm{CC}$ culture strains exposed to dipyridyl and $\mathrm{H}_{2} \mathrm{O}_{2}$.

\begin{tabular}{|c|c|c|c|c|c|c|}
\hline \multirow[t]{2}{*}{ Strain } & \multirow[t]{2}{*}{ Substitution } & \multirow{2}{*}{$\frac{\text { Dipyridyl }+0 \mathrm{mM} \mathrm{H}_{2} \mathrm{O}_{2}}{\text { Mut } / 10^{8} \text { cell }}$} & \multicolumn{2}{|c|}{ Dipyridil + $15 \mathrm{mM} \mathrm{H}_{2} \mathrm{O}_{2}$} & \multicolumn{2}{|c|}{ Dipyridyl + $20 \mathrm{mM} \mathrm{H}_{2} \mathrm{O}_{2}$} \\
\hline & & & Mut $/ 10^{8}$ cell & Fold increase & Mut $/ 10^{8}$ cell & Fold increase \\
\hline CC101 & $A: T \rightarrow C: G$ & $2.4 \pm 0.5$ & $4.8 \pm 0.1$ & 2.0 & $8.6 \pm 2.0$ & 3.5 \\
\hline CC102 & $\mathrm{G}: \mathrm{C} \rightarrow \mathrm{A}: \mathrm{T}$ & $0.5 \pm 0.1$ & $68.7 \pm 4.7^{*}$ & 135.8 & $138.9 \pm 40.8^{*}$ & 275.0 \\
\hline CC103 & $\mathrm{G}: \mathrm{C} \rightarrow \mathrm{C}: \mathrm{G}$ & $0.8 \pm 0.1$ & $5.9 \pm 3.4$ & 7.2 & $2.2 \pm 1.3$ & 2.7 \\
\hline CC104 & $\mathrm{G}: \mathrm{C} \rightarrow \mathrm{T}: \mathrm{A}$ & $16.7 \pm 6.9$ & $25.0 \pm 7.0$ & 1.5 & $14.1 \pm 1.3$ & 0.8 \\
\hline CC105 & $\mathrm{A}: \mathrm{T} \rightarrow \mathrm{T}: \mathrm{A}$ & $0.7 \pm 0.1$ & $15.1 \pm 8.8$ & 20.2 & $56.9 \pm 21.0$ & 76.0 \\
\hline CC106 & $A: T \rightarrow G: C$ & $1.4 \pm 0.2$ & $0.6 \pm 0.1$ & 0.4 & $0.9 \pm 0.0$ & 0.6 \\
\hline
\end{tabular}

Cultures in the mid-exponential phase of growth in M9S medium at $37^{\circ} \mathrm{C}$ under shaking were pretreated with 1 $\mathrm{mM}$ dipyridyl for $20 \mathrm{~min}$ and then exposed to $\mathrm{H}_{2} \mathrm{O}_{2}$ treatment for $20 \mathrm{~min}$. The data represent the mean of at least 3 experiments. ${ }^{*} \mathrm{P}<0.01$ compared to all other strains (Tukey-Kramer test). 
response (15).

The appearance of $A: T \rightarrow T: A$ is consistent with a preference for adenine ( $A$ rule) insertion in the bypass at AP sites (16). Therefore, we assume that our observation is consistent with the production of AP sites, a well-known type of oxidative DNA damage (17), after exposure to high $\mathrm{H}_{2} \mathrm{O}_{2}$ concentrations. However, we cannot exclude the possibility of another oxidative base damage, such as 2-hydroxyadenine, that can also induce $A: T \rightarrow T: A$ transversion by mispairing with adenine. The accumulation of 2-hydroxyadenine is reported to occur after $\mathrm{H}_{2} \mathrm{O}_{2}$ treatment in human cells $(18,19)$.

The clear preferential induction of $\mathrm{G}: \mathrm{C} \rightarrow \mathrm{A}: \mathrm{T}$ transition by high $\mathrm{H}_{2} \mathrm{O}_{2}$ upon iron deprivation indicates that the nature of DNA base damage induced by this challenge may be different from that induced by $\mathrm{H}_{2} \mathrm{O}_{2}$ alone. The occurrence of 8oxo-G as well as AP sites due to damaged guanine in DNA does not support the appearance of this transition. Both lesions would produce $\mathrm{G}: \mathrm{C} \rightarrow \mathrm{T}$ :A as a result of mispairing between 80xo-G with $A$ or by preferential insertion of adenine at an AP site (20). This led us to focus on cytosine as the main target for DNA lesion induced by $\mathrm{H}_{2} \mathrm{O}_{2}$ upon iron ion deprivation.

Hydroxyl ion reacts with cytosine by adding to the C5$\mathrm{C} 6$ double bond leading to the formation of cytosine glycol, which is unstable and can break down further to 5-hydroxy2'deoxycytosine (5-OHdC), 5-hydroxy-2'deoxyuracil (5$\mathrm{OHdU}$ ) and uracil glycol $(21,22)$. The major stable oxidation product of cytosine is $5-\mathrm{OHdU}$ that preferentially pairs with

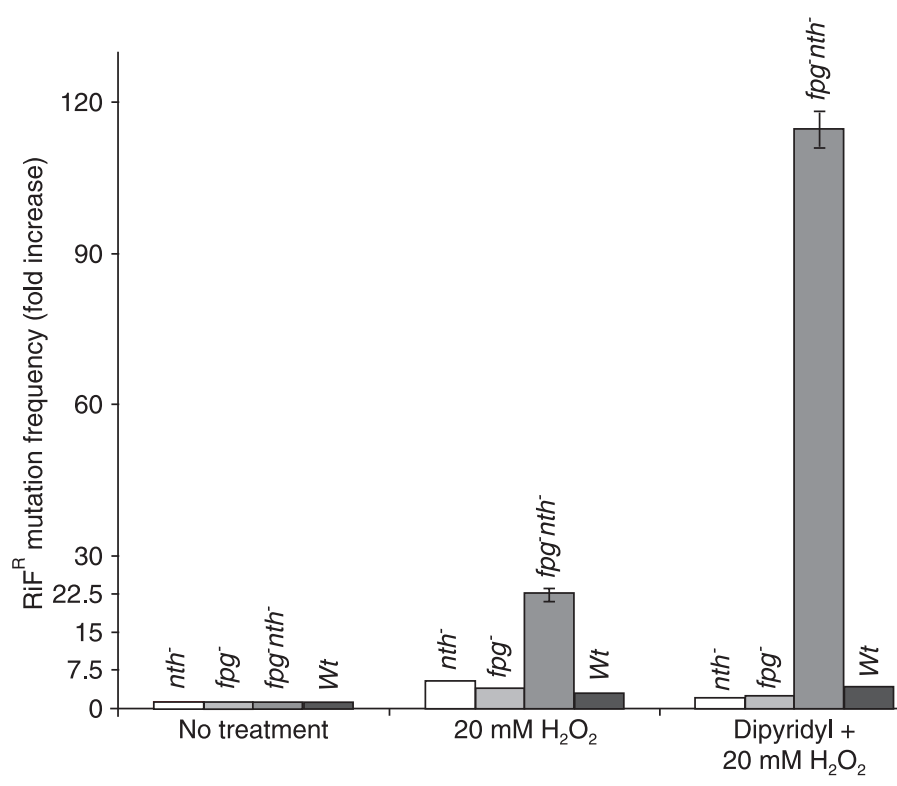

Figure 1. Mutagenesis of Escherichia coli cultures exposed to dipyridyl and $\mathrm{H}_{2} \mathrm{O}_{2}$. Cultures in the mid-exponential phase of growth in M9S medium at $37^{\circ} \mathrm{C}$ under shaking were pretreated or not with $1 \mathrm{mM}$ dipyridyl for 20 min and then submitted to $\mathrm{H}_{2} \mathrm{O}_{2}$ treatment for 5 min. adenine (13). 5-Hydroxy-2'deoxyuracil shares this same property and it would also result in the $\mathrm{G}: \mathrm{C} \rightarrow \mathrm{A}: \mathrm{T}$ transition $(19,23)$. Whenever $5-O H d C$ is present in DNA, it is removed by the action of endonuclease III (Nth) via the $\mathrm{N}$-glycosylase/ $\beta$ elimination reaction, by the formamidopyrimidine-DNA glycosylase (Fpg) via the $\mathrm{N}$-glycosylase/ $\beta, \delta$ elimination reaction $(24,25)$ in $E$. coli or by their homologs in eukaryotes $(26,27)$. Nth and Fpg can remove $5-\mathrm{OHdU}$ from DNA through the cited mechanisms and additionally by uracil DNA N-glycosylase (Ung) generating AP sites (25).

Mutagenesis induced by $20 \mathrm{mM} \mathrm{H}_{2} \mathrm{O}_{2}$ upon iron deprivation in the $r p o B$ gene, performed as described by Sedgwick and Goodwin (12), was evaluated using either nth and fpg single mutants or double mutants. A higher mutation frequency was detected in the double mutant (Figure 1) for both conditions. We detected a 110 -fold increase in mutation frequency in dipyridyl-pretreated cells and a 20-fold increase in cultures not treated with the metal chelator, suggesting the appearance of additional and/or different lesions in cells challenged with $\mathrm{H}_{2} \mathrm{O}_{2}$ upon iron deprivation. In both cases the sum of the mutation frequency observed in the single mutants did not correspond to that observed in the double mutant. This behavior may indicate that both $n t h$ and fpg share a role in preventing the appearance of mutagenic lesions. We suggest that $5-\mathrm{OHdC}$ and $5-\mathrm{OHdU}$ are the premutagenic DNA lesions produced by the challenge of $\mathrm{H}_{2} \mathrm{O}_{2}$ in iron-depleted cultures. We assume that the $\mathrm{G}: \mathrm{C} \rightarrow \mathrm{A}: \mathrm{T}$ transition would be due to the mispairing of damaged cytosine, in this case $5-\mathrm{OHdC}$, with adenine. In the case of $5-\mathrm{OHdU}$ we can speculate that it would be converted to an AP site, since Ung is active in nth fpg double mutants, leading to base substitution of $\mathrm{C}$ to $\mathrm{T}$ as a consequence of the preference for adenine insertion during translesion synthesis at an AP site. The nature of base substitution in the $n t h, f p g$ and $n$th fpg background is presently under investigation by our group.

We suggest that lethal and mutagenic pathways produced by high concentrations (more than $15 \mathrm{mM}$ ) of $\mathrm{H}_{2} \mathrm{O}_{2}$ in $\mathrm{E}$. coli under iron deprivation might be a result of cytosine oxidation, yielding their mutagenic products $5-\mathrm{OHdC}$ and/or 5-OHdU. Taken together, our data support the hypothesis of two different pathways for $\mathrm{H}_{2} \mathrm{O}_{2}$-induced lesions upon iron deprivation, which depend on $\mathrm{H}_{2} \mathrm{O}_{2}$ concentration.

\section{Acknowledgments}

We are grateful to J.S. Cardoso for expert technical assistance and to D.P. Carvalho and M. Pádula for help and discussion during the preparation of the manuscript. 


\section{References}

1. Imlay JA, Linn S. Bimodal pattern of killing of DNA-repairdefective or anoxically grown Escherichia coli by hydrogen peroxide. J Bacteriol 1986; 166: 519-527.

2. Imlay JA, Chin SM, Linn S. Toxic DNA damage by hydrogen peroxide through the Fenton reaction in vivo and in vitro. Science 1988; 240: 640-642.

3. Asad NR, Leitao AC. Effects of metal ion chelators on DNA strand breaks and inactivation produced by hydrogen peroxide in Escherichia coli: detection of iron-independent lesions. J Bacteriol 1991; 173: 2562-2568.

4. Asad NR, Asad LMBO, Almeida CE, Felzenszwalb I, CabralNeto JB, Leitão AC. Several pathways of hydrogen peroxide action that damage the E. coli genome. Gen Mol Biol 2004; 27: 291-303

5. Luo Y, Han Z, Chin SM, Linn S. Three chemically distinct types of oxidants formed by iron-mediated Fenton reactions in the presence of DNA. Proc Natl Acad Sci U S A 1994; 91: 12438-12442.

6. Souza LL, Eduardo IR, Padula M, Leitao AC. Endonuclease IV and exonuclease III are involved in the repair and mutagenesis of DNA lesions induced by UVB in Escherichia coli. Mutagenesis 2006; 21: 125-130.

7. Almeida CE, Galhardo RS, Felicio DL, Cabral-Neto JB, Leitao AC. Copper ions mediate the lethality induced by hydrogen peroxide in low iron conditions in Escherichia coli. Mutat Res 2000; 460: 61-67.

8. Asad NR, de Almeida CE, Asad LM, Felzenszwalb I, Leitao AC. Fpg and UvrA proteins participate in the repair of DNA lesions induced by hydrogen peroxide in low iron level in Escherichia coli. Biochimie 1995; 77: 262-264.

9. Asad LM, Asad NR, Silva AB, de Almeida CE, Leitao AC. Role of SOS and OxyR systems in the repair of Escherichia coli submitted to hydrogen peroxide under low iron conditions. Biochimie 1997; 79: 359-364.

10. Galhardo RS, Almeida CE, Leitao AC, Cabral-Neto JB. Repair of DNA lesions induced by hydrogen peroxide in the presence of iron chelators in Escherichia coli: participation of endonuclease IV and Fpg. J Bacteriol 2000; 182: 19641968.

11. Cupples CG, Miller JH. A set of lacZ mutations in Escherichia coli that allow rapid detection of each of the six base substitutions. Proc Natl Acad Sci U S A 1989; 86: 5345-5349.

12. Sedgwick SG, Goodwin PA. Differences in mutagenic and recombinational DNA repair in enterobacteria. Proc Natl Acad Sci U S A 1985; 82: 4172-4176.

13. Miller JH. A short course in bacterial genetics: a laboratory manual and handbook for E. coli and related bacteria. Cold Spring Harbor: Cold Spring Harbor Lab. Press; 1992.

14. Coulondre C, Miller JH. Genetic studies of the lac repressor. III. Additional correlation of mutational sites with specific amino acid residues. J Mol Biol 1977; 117: 525-567.
15. Schaaper RM, Loeb LA. Depurination causes mutations in SOS-induced cells. Proc Natl Acad Sci U S A 1981; 78: 1773-1777.

16. Kunkel TA. Mutational specificity of depurination. Proc Natl Acad Sci U S A 1984; 81: 1494-1498.

17. Wallace SS. Biological consequences of free radical-damaged DNA bases. Free Radic Biol Med 2002; 33: 1-14.

18. Jaruga P, Dizdaroglu M. Repair of products of oxidative DNA base damage in human cells. Nucleic Acids Res 1996; 24: 1389-1394.

19. Kamiya $\mathrm{H}$. Mutagenic potentials of damaged nucleic acids produced by reactive oxygen/nitrogen species: approaches using synthetic oligonucleotides and nucleotides: survey and summary. Nucleic Acids Res 2003; 31: 517-531.

20. Wood ML, Dizdaroglu M, Gajewski E, Essigmann JM. Mechanistic studies of ionizing radiation and oxidative mutagenesis: genetic effects of a single 8-hydroxyguanine (7-hydro-8-oxoguanine) residue inserted at a unique site in a viral genome. Biochemistry 1990; 29: 7024-7032.

21. Cooke MS, Evans MD, Dizdaroglu M, Lunec J. Oxidative DNA damage: mechanisms, mutation, and disease. FASEB J 2003; 17: 1195-1214.

22. Dizdaroglu M, Holwitt E, Hagan MP, Blakely WF. Formation of cytosine glycol and 5,6-dihydroxycytosine in deoxyribonucleic acid on treatment with osmium tetroxide. Biochem $J$ 1986; 235: 531-536.

23. Kreutzer DA, Essigmann JM. Oxidized, deaminated cytosines are a source of $\mathrm{C} \rightarrow \mathrm{T}$ transitions in vivo. Proc Natl Acad Sci U S A 1998; 95: 3578-3582.

24. Cadet J, Bourdat AG, D'Ham C, Duarte V, Gasparutto D, Romieu A, et al. Oxidative base damage to DNA: specificity of base excision repair enzymes. Mutat Res 2000; 462: 121-128.

25. Hatahet Z, Kow YW, Purmal AA, Cunningham RP, Wallace SS. New substrates for old enzymes. 5-Hydroxy-2'-deoxycytidine and 5-hydroxy-2'-deoxyuridine are substrates for Escherichia coli endonuclease III and formamidopyrimidine DNA N-glycosylase, while 5-hydroxy-2'-deoxyuridine is a substrate for uracil DNA N-glycosylase. J Biol Chem 1994; 269: 18814-18820.

26. Hilbert TP, Boorstein RJ, Kung HC, Bolton PH, Xing D, Cunningham RP, et al. Purification of a mammalian homologue of Escherichia coli endonuclease III: identification of a bovine pyrimidine hydrate-thymine glycol DNAse/AP lyase by irreversible cross linking to a thymine glycol-containing oligoxynucleotide. Biochemistry 1996; 35: 2505-2511.2

27. Melo RG, Leitao AC, Padula M. Role of OGG1 and NTG2 in the repair of oxidative DNA damage and mutagenesis induced by hydrogen peroxide in Saccharomyces cerevisiae: relationships with transition metals iron and copper. Yeast 2004; 21: 991-1003. 